\title{
Interactive comment on "Fluid-mediated, brittle-ductile deformation at seismogenic depth: Part I - Fluid record and deformation history of fault-veins in a nuclear waste repository (Olkiluoto Island, Finland)" by Barbara Marchesini et al.
}

Vanderhaeghe (Referee)

olivier.vanderhaeghe@get.omp.eu

Received and published: 3 February 2019

The paper untitled "Fluid-mediated, brittle-ductile deformation at seismogenic depth: Part I- Fluid record and deformation history of fault-veins in a nuclear waste repository (Olkiluoto Island, Finland)" submitted for publication to Solid Earth by Marchesini et al. presents a nice multi-method study combining microstructural and fluid inclusion analysis on samples properly integrated in their tectonic context. The problematic is correctly integrated in its general scientific context (I only mentioned some potential additional references) and the topic is of interest to a wide range of geoscientist. The 
paper is clearly-organized, well-written and nicely illustrated. The data are robust and the reasoning appears sound for most of it. The discussion is interesting and farreaching although it somehow overstates the significance of the analysis of a couple quartz veins sampled in a subvertical shear zone, which relevance with regard to other veins in the studied area and as proper tracers of "the" brittle/ductile transition is not clearly established. For these reasons, I think that this paper meets the criteria to be published at the condition that the few issues raised below are addressed.

\section{Microstructural analysis}

The core of this paper is based on a microstructural analysis of quartz veins localized in a subvertical shear zone with a clear polyphased history marked by crosscutting structures and by changes in kinematics. The analysis of this shear zone is based on quartz veins sampled in the core zone of this shear zone and also in the surrounding damage zone. The authors invoke the alternation of ductile and brittle deformation based on the discordant position of the early quartz veins relative to the foliation of the host rock, on recrystallization of these early quartz grains, and on fractures crosscutting these veins, some of which are associated with secondary quartz grains.

So far, the reasoning appears pertinent. Yet, I would like to clarify one point. In the microstructural description of quartz veins, the authors refer to "new quartz grains" (illustrated in figure $6 \mathrm{~d}$ ?). After reading the text, it is not clear to me if the authors attribute these "new quartz grains" to quartz that have precipitated from a fluid that has circulated into a fracture or to neoblasts formed by solid-state recrystallization? From the pictures, I would favor solid-state recrystallization but I have the impression that the authors rather imply precipitation in a fracture. Clarify.

Fluid inclusion analysis

Printer-friendly version

The fluid inclusion analysis follows a standard procedure of the identification of different types according to their microstructural position, followed by heating-cooling on a microthermometric stage combined with Raman spectrometry. I do not understand 
why, after such an analysis, the composition of the fluid is not specified, except for its salinity in $\mathrm{NaCl}$ equivalent? Are they $\mathrm{CO} 2$ and/or $\mathrm{H} 2 \mathrm{O}$ fluid inclusions? Moreover, in which state are they? Liquid or vapor? Please provide these informations. I am also surprised that only secondary trails and pseudosecondary trails have been identified. Please confirm that there are no primary fluid inclusions forming clusters in the core of quartz grains. It might also be useful distinguish intracrystalline fluid inclusions trails from fluid inclusion trails crosscutting quartz grains.

The use of the term transposition referring to fluid inclusion trails (line 362) is confusing. What is the meaning of the term "transposition" in this context? In structural geology, as far as I know, transposition corresponds to reorientation of a former structure during deformation. I don't think that it applies to the present case according to what is illustrated in figure 9c. I imagine that what is meant is "remobilization" or "redistribution" of the fluids contained in these trails as a consequence of recrystallization. Clarify.

The homogenization temperatures and salinities obtained on the analysis of what is presented as a consistent assemblage of fluid inclusions display rather wide ranges of values. The authors explain this diversity by post-entrapment modification of the fluid inclusions and argue paradoxically that these fluid inclusions with variable characteristics correspond to a homogeneous fluid. As an alternative, I would suggest to consider that these fluid inclusions do not belong to the same "population" or "type" and search for criteria to subdivide the studied assemblages in subsets. The identification of the proportion of $\mathrm{CO} 2$ and $\mathrm{H} 2 \mathrm{O}$ might provide insights to refine the analysis of fluid types.

The nature of the fluid inclusions might also deliver some clues to discuss the source of these fluids, which is key to determine the geometry of fluid circulation in the crust (upward or downward), which is, to some degree, eluded in this paper.

Deformation and fluid circulation model

The authors propose a model of repeated brittle-ductile deformation cycle triggered by successive fluid overpressure and evacuation, which is in essence similar to the fault 
valve model published in several papers by Sibson or Cox, with the nuance that the authors advocate that the studied shear zone is representative of "the" brittle/ductile transition at the time of deformation. It is not clear to me how this is demonstrated by the data, especially with regard to a subvertical strike-slip shear zone. Ideally, it should be demonstrated that at higher structural level, brittle deformation dominates and that at lower structural level, ductile deformation dominates. Is this the case? Moreover, the authors propose that the shear zone records deformation during progressive exhumation and cooling, which, as far as I understand, is not consistent with the increase in $\mathrm{P}$ and $\mathrm{T}$ recorded from $\mathrm{t} 1$ to $\mathrm{t} 2$ (and even $\mathrm{t} 3$ when considering the temperature). In order to clarify these points, it is required to discuss the significance of the measures pressure and temperature. Does the pressure correspond to the fluid pressure required for embrittlement, i.e. the yield strength of the host rock or does it correspond to the lithostatic or even hydrostatic pressure? Are the measured temperatures representative of the host rock temperature or do they solely reflect the fluid temperature? In the latter case, is it possible to document if the fluid temperature is higher or lower than the temperature of the host rocks? A related question is where the fluid does come from and where does it go?

At last, the authors consider that the studied shear zone is narrowing implying that the damage zone is representative of an early stage of brittle deformation, which is followed by ductile/brittle deformation localized in the core of the shear zone. This assumption strongly controls the interpretation of the data and the elaboration of the fluid circulation/deformation model. As an alternative, one could consider that the fault zone is widening rather than narrowing. In this case, the damage zone represents a more recent expression of the fault zone than the core zone that has experienced a longer history of deformation. Note that this proposition is in line with the lower temperature and pressure recorded by the fluid inclusions in the damage zone compared to the core zone of the fault, suggesting progressive exhumation of the shear zone during deformation. Please consider this alternative and provide evidences to discard (or favor?) it.

Printer-friendly version

Discussion paper
Interactive

comment 
A few more comments and corrections are mentioned in the annotated version of the manuscript. I hope that these will help improve this paper and I will be pleased to read a revised version of the manuscript upon request. Below are a list of publications that are quoted in my review. I apologize for shamelessly quoting some of my own contributions, but these are the ones I know the best!

Regards, Olivier Vanderhaeghe.

\section{References}

Boiron, M.C., Cathelineau, M., Banks, D.A., Fourcade, S., 2003. Mixing of metamorphic and surficial fluids during the uplift of the Hercynian upper crust: consequences for gold deposition. Chem. Geol. 194, 119-141.

Famin, V., Philippot, P., Jolivet, L., Agard, P., 2004. Evolution of hydrothermal regime along a crustal shear zone, Tinos Island, Greece. Tectonics 23, 1-23.

Famin, V.,Hébert, R., Philippot, P., Jolivet, L., 2005. Ion probe and fluid inclusion evidence for coseismic fluid infiltration in a crustal detachment. Contrib. Mineral. Petrol. 150, 354-367.

Moritz, R., Ghazban, F., Singer, B.S., 2006. Eocene gold ore formation at Muteh, Sanandaj-Sirjan tectonic zone, western Iran: a result of late-stage extension and exhumation of metamorphic basement rocks within the Zagros orogen. Econ. Geol. 101 (8), 1497-1524.

Morrison, J., 1994. Meteoric water-rock interaction in the lower plate of the Whipple Mountain metamorphic core complex, California. J. Metamorph. Geol. 12 (6), 827840.

Morrison, J., Anderson, J.L., 1998. Footwall refrigeration along a detachment fault: implications for thermal evolution of core complexes. Science 279, 63-66.

Mulch, A., Teyssier, C., Cosca, M. et al., 2004. The hydrogen isotope record of detach- 
ment mylonites: a new method for reconstructing paleoelevations of eroded orogens. Geology, 32, 525-528.

Scheffer, C., Tarantola, A., Vanderhaeghe, O., Voudouris, P., Rigaudier, T., Photiades, A., Morin, D., and Alloucherie, A., 2017b, The Lavrion Pb-Zn-Fe-Cu-Ag detachmentrelated district (Attica, Greece): Structural control on hydrothermal flow and element transfer-deposition. Tectonophysics, v. 717, p. 607-627.

Interactive

comment

Scheffer, C., Tarantola, A., Vanderhaeghe, O., Rigaudier, T., Photiades, A., 2017. CO2 flow during orogenic gravitational collapse: Syntectonic decarbonation and fluid mixing at the ductile-brittle transition (Lavrion, Greece). Chem. Geol. 450, 248-263.

Siebenaller, L., Boiron, M.C., Vanderhaeghe, O., Hibsch, C., Jessell, M.W., AndréMayer, A.S., France-Lanord, C., Photiades, A., 2013. Fluid record of rock exhumation across the brittle ductile transition during formation of a Metamorphic Core Complex (Naxos Island, Cyclades, Greece). J. Metamorph. Geol. 31, 313-338.

Please also note the supplement to this comment:

https://www.solid-earth-discuss.net/se-2019-5/se-2019-5-RC1-supplement.pdf

Interactive comment on Solid Earth Discuss., https://doi.org/10.5194/se-2019-5, 2019. 